\title{
Varieties of Belief in Nichiren Buddhism in Modern Japan
}

\author{
Miwa Zehō
}

\section{Introduction}

This study is research and the consideration about a man who had faith in Nichiren 日蓮 Buddhism in modern Japan, to confirm the psychological influence of Nichiren Buddhism on each believer. ${ }^{1)}$ In this report we will consider Kojima Ainosuke 小島愛之助 (18841973), who started a budget hotel named 'Hokke Club 法華クラブ, that is open even now in front of Kyoto Station.

Before he began the hotel, he was staging the 'Tōitsu-Bushi' 統一節, which was a short performance about Nichiren's biography, to spread belief in Nichiren Buddhism in many parts of Japan. At that time his name was 'Utsunomiya Tarō’ 宇都宮太郎, and he performed as a professional storyteller.

We will consider Kojima's faith during the following periods in his life in the Taisho Era: 1. From the initiation to his life performing on tour (1912-1920), 2. The marriage with Tamao 玉雄 (1918), 3. The birth of his eldest son, Isondo 五十人 (1921), 4. The death in early life of his second son, Yoshio 善男 (1924).

The information materials used in this research are diaries written by Kojima from 1913 to 1924 . The diaries from 1914 were burned, so beyond that, we have researched based on books written by Isondo, “Syūshiikkan” 終始一貫 (From Beginning to End) and “Yumino-chikara” 弓の力 (The Power of Bow), internal magazines in Hokke Club, named “Inori” いのり (Devotion), from no. 1 in 1958 to no. 199 in 1975. ${ }^{2}$

\section{Birth}

Kojima Ainosuke was born on 19th June 1884 in Hyōgo prefecture in Japan. Kojima was the second son of seven brothers and sisters. His father plied a trade, bought rice and so on. When he was six, his mother died, aged 45 . After 5 years, his father also died, aged 55. Ko- 
jima dropped out of school in that year when his father died in order to help his older brother, who was 17 years old and had to pursue the family business. Kojima resolved to go to Kyoto and find a job to assist his brother. He was 19 years old in 1903. Kojima grew exhausted emotionally, so he went back home in 1912. On 31st August that year, by a mere accident, he viewed a short play named 'Tōitsu-Bushi' in the great hall in the country inn.

'Tōitsu-Bushi' was storytelling of the passing on Nichiren's biography. Although we cannot know how the stories had been told, the name of the professional storyteller was 'Utsunomiya Mondonosuke’ 宇都宮主計之助. That was a man whom Kojima called his master in his life, and who was a propagandist of 'Nichirenism' 日蓮主義. His real name was Senō Hajime 妹尾朔 (1880-?). It was the first contact for Kojima to know about Nichiren. After that Kojima went about his daily storytelling under the name of 'Utsunomiya Tarō.'

\section{Senō Hajime and Tōitsu-Bushi}

Next, we will discuss Senō Hajime, who produced the 'Tōitsu-Bushi.' Now, because Senō's family line was discontinued, we cannot discover directly related documents. It is possible for us to read only the oral biography that Isondo had heard from Teruko, Senō's only daughter. ${ }^{3)}$

Senō Hajime was born on 25th August in 1880 in Okayama prefecture. Living in the house of an advocate in Okayama prefecture, Senō had concentrated on his study. After that, he went on to Tokyo Teikoku University 東京帝国大学 and majored in philosophy, getting a diploma in 1906.

Senō was studying religion while in University, for example Shintoism, Buddhism and Christianity, and had gotten into the religion of Christianity at some point. Around the same time, he heard a lecture by Honda Nishō 本多日生, and allegedly Senō contended with Honda. After graduating, he entered the journalism company Yorozu-chō-hō 万朝報, led by Kuroiwa Ruikō 黒岩涙香, and wrote for their journal. Senō emigrated from Tokyo to Kyoto in 1909, and established the Kyoto-Beneficence-Hospital 京都慈善救護院 and the Kyoto-Beneficence-New-Journal-Cooperation 京都慈善新報社. While managing welfare projects, he started performance of the "Tōitsu-Bushi," reciting Nichien's biography in simple terms bearing the flag of “Honge-Geijutsu-Fukyō-Dan” 本化芸術布教団 (an artistic mission group) and identifying himself as 'Utsunomiya Mondonosuke.' 
There were three people in Senō's family: Senō, his wife Toshiko and his daughter Teruko. Teruko was a doctor in private practice at home. Kojima had helped her financially to practice. Senō's daughter, Teruko died around 2010, without ever marrying. The remains of the Senō family are buried in Senō’s tomb in Honkyō-ji 本経寺 in his hometown Okayama. ${ }^{4}$

By the way, 'Tōitsu-Bushi' was composed of 26 verses, presumably all written by Senō. The explanation of Isondo is as follows: 'Tōitsu-Bushi' was a Sekkyō-Bushi 説経節(homily, telling St. Nichiren's biography depending on the time and place through assembling beautiful methods of expression in Japan, for example Kouta 小唄, Biwa 琵琶, Kiyomoto 清元, Tokiwazu 常磐津, Joruri 浄瑠璃, Gidayu 義太夫, Shinnai 新内, Oiwake 追分 etc., because there were few people who could understand his biography at the end of Meiji era. ${ }^{5)}$ Unfortunately, we have not been able to discover the original "St. Nichiren's biography" written by Senō, but there are some versions that were copied for performance by Kojima.

The versions that Kojima copied doubled a musical score, writing a red line to read with inflection and 'emphasis' in katakana. "St. Nichiren's biography" had been published three times. The first printing was done in 1912 by Hērakuji-Shoten 平楽寺書店 and IkuēSha 育英社 (publishing companies). After that, this book was printed twice from HokkeClub, the hotel group that Kojima had begun.

The titles of the sections in "St. Nichiren's biography” were as follows: 'Background,' 'Awa 安房-country, The wonder calm of fleet,' 'Kiyosumi-dera 清澄寺, the farewell of a master and a pupil,' 'Komachi-ga-tuji 小町ヶ辻, falling tiles and stones like rain,' 'A house at Nagoe 名越, one autumn night,' 'Ebara 荏原 village, one summer day, 'In the edifice of the Kamakura Shogunate, one bloody volume,' 'At Matsuba-ga-yatsu 松葉ヶ谷, a swirl of smoke,' 'At Yui-ga-hama 由比ヶ浜, the farewell of a master and pupil,' 'The sea of Izu 伊 豆, a floating ship in the sky, “ A whole heart of Funamori Yasaburō’s 船守弥三郎 wedded pair, ‘The errantry of Saimyōji-nyudō Tokiyori 西明寺入道時頼, ’ ‘At Komatsubara 小松原, the hot blood like the sea (part 1) (part 2),' 'Mt. Gankō 岩高山, the prestigious cowl,' ‘The diplomatic document from Menggu 蒙古,' ‘The crest of Mt. Fuji,' 'Monk Ryōkan’s 良観 rain-making rituals,' 'The mandate for a capital crime,' 'The memorial fifth volume of the Lotus Sutra,' 'At Tatsunokuchi龍の口, the trajectory of sword in midnight,' 'Echi 依智 village, the letter with emotion,' 'At Sado-island 佐渡ヶ島, snow-deep Tsukahara 塚原 (part 1) (part 2), 'The pardon,' and 'The meeting with Tokimune 時宗.'

Though we are currently still studying what texts of Nichiren's biography Senō used 
to write his "St. Nichiren's biography," we will point out a few aspects of content. 1. There are no more than two citations of passages from The Lotus Sutra, "If there is any sick person who hears this Sutra, his illness will disappear, and he will neither die nor grow old” in “Ancient Accounts of the Bodhisattva Bhaisạjyarāja” and "I am always thinking: By what means can I make sentient beings able to/ Enter the highest path /And quickly attain the Dharma?" in "The Life-span of the Tathāgata." 2. Out of all in Nichiren's writings, only “Rissho-Ankoku-Ron” 立正安国論 appears by name. 3. Nichiren in his period at Mt. Minobu 身延山 was never discussed.

\section{Kojima Ainosuke's faith in Nichiren Buddhism}

Kojima Ainosuke came to believe in Nichiren Buddhism after encountering Tōitsu-Bushi. Next, we will consider how Kojima's faith deepened on basis of his diaries, which were written from 1913 when Kojima started touring Japan.

The diaries from 1913 to 1916 give the impression that they were journals making a record of wake-up time, travel, location of performance, the number of people in the audiences and the titles of sections of Töitsu-Bushi performed. Based on those descriptions, we think that as Kojima was writing the journal, he was attracted to the skills needed to perform Tōitsu-Bushi and devoted himself to mastering those skills.

\section{A. Initiation and traveling, from a performance to the faith}

Kojima became a disciple of Seno and received the name 'Utsunomiya Tarō' in 1912. He trained in the performance of Tōitsu-Bushi and traveled with Senō on tour.

Kojima first performed at Hokekyō-ji 法華経寺 in Chiba on 12th January 1913. The next day, he did two stages, day and night. He wrote as follows:

From the opening curtain at p.m.7, I played 'Awa-country, The wonder calm of fleet' and 'Kiyosumitemple, the farewell of a master and a pupil,' then my master played 'The sea of Izu, a floating ship in the sky' and 'At Tatsunokuchi, the trajectory of sword in midnight,' down curtain ... The crowd joined their hands in prayer toward not only my master but also to me during the performances. I had my first taste of being bowed to by other men. Therefore I was delighted at playing TōitsuBushi, and at the same time my faith developed.

Here we see that Kojima was moved by the praying crowd who professed Nichiren Buddhism. Seeing them with his own eyes, Kojima wrote about how his faith was deepening. "I was delighted at playing Tōitsu-Bushi." He was greatly attracted to the performing 
art of Tōitsu-Bushi, dramatically singing Nichiren's biography, and moved through his own performance.

And from the diary of 21st February 1913, we can understand that Kojima increased his knowledge of Nichiren. In a place where he stayed, he talked to believers about Nichiren: "After eating rice cakes at dinner, I talked to Mr. Ichihara, a primary school principal in Chiba, about Nichiren's personal quality, and I read Nichiren's works for the first time today." That is to say, Kojima did not have literature of Nichiren other than books that Senō wrote, but here Kojima gained the chance of directly reading Nichiren's writings. However, we do not know what kind of publication of Nichiren's writings he read. After that, his favorite book of Nichiren's writings was “Ruisan-Koso-Ibunroku” 類纂高祖遺文録, edited by Tanaka Chigaku 田中智学.

In the diary of May 1913, we note that Kojima felt 'St. Nichiren's protective power' because although he had been in a traffic accident, Kojima had no injury. Then when he went back Kyoto, Kojima copied Seno's writing books of Nichiren's life from 13th to 15th May. ${ }^{7)}$

\section{B. The marriage with Tamao}

On the 1st of January in 1918, Kojima married Tamao 玉雄 in front of a Buddhist image. One feature of the diary in this year is that Kojima wrote the Daimoku in his diary for the first time on the 25th of October, although he previously wrote it in his travel book. On 7th December, he wrote the Odaimoku in gratitude for Nichiren's protective power.

By the way, we think that Kojima enriched his faith by marrying Tamao, because Kojima became aware of the responsibilities of being a head of a family and educating her in Nichiren Buddhism while he lived with Tamao and his mother-in-law. Kojima first wrote an optative sentence and a passage from Nichiren's writing, “Shohōjissō-syō” 諸法実相鈔, using the words 'St. Nichiren said' on the edge of page in his diary of January 1st 1919. On the 1st of January, all of the family chanted the Daimoku a long time in front of the Principal Image, he wrote in the diary. As Kojima became conscious of his obligation to spread the faith, the task of writing his diaries changed from a daily task to an opportunity to profess his faith. On 2nd, he wrote a vow to not forget to read The Lotus Sutra."

Part of Tamao's education was a visit to Minobusan. They visited Minobusan in September of 1919 for the first time. The next day, Kojima and Tamao visited Shisin-hall 思親 閣 in the rain, went back to the inn around at p.m. 4 and finished dinner, then went to the main-hall. Kojima performed Tōitsu-Bushi at Kuon-ji 久遠寺 for the first time from p.m. 
7:30 for an hour and a half. The parts performed were "In the edifice of the Kamakura Shogunate, one bloody volume,' connected “Rissho-Ankoku-ron,” 'At Sado -island, snow-deep Tsukahara (part 1)' and '(part 2). ${ }^{10)}$ When he paid his respects at the hall putting in Nichiren's ash, Kojima cried loudly unconsciously. ${ }^{11)}$

\section{The birth of Kojima's eldest son, Isondo}

Kojima's eldest son was born in 1921. About the same time, traveling to every region of Japan for Tōitsu-Bushi, while he had begun Hokke-Club on 12th September, Kojima and Tamao were pressed by business.

Though the 1921 diary had many blank pages, on 26th August words line the whole page, because the eldest son Isondo was born. If we believe this diary, the reason why Kojima had Isondo was that Seno had invoked the birth of a first child. ${ }^{12)}$ He communicated with the Seno family in a hurry. Kojima wrote this as a final sentence in the diary:

In front of The Three Treasures of the Buddha, Dharma and Priest, I want to show my gratitude and my thankfulness, so I will read The Lotus Sutra and chant Odaimoku. I make an everlasting wish for purging my son's sins, for developing my son's faith, and for raising my son into a person of integrity who can help widely spread The Lotus Sutra according to Nichiren's teaching. Believing in the Lotus Sutra, Namu-Myō-Hō-Ren-Ge-Kyō 南無妙法蓮華経.

\section{The death of the second son, Yoshio}

Into 1924, Senō had conceived a new way to proselytize. The way was a movie. Senō and Kojima established a company named 'Rissho-Katsuē corporation'立正活映株式会社. With this establishment, Kojima frequently traveled for a long time making contracts with owners of performance locations. When he walked around to secure a place in Nagasaki prefecture of Kyūshū, Kojima learned that his second son, Yoshio, had become ill by telegram. He wrote in his confusion as follows:

Alas, things went wrong, I goofed, I made a huge mistake, what should I do, when I think of the hope of Yoshio's life, it went sour. What now? Should I go home or not, what should I do? I want to go home because of father-child attachment, but perhaps I should not go home. ${ }^{13)}$

Kojima decided to keep working and not to go home after being in a muddle, because his work was 'an important role of spreading The Lotus Sutra, ${ }^{\text {'14) }}$ and actually, his travel had two missions: disseminating The Lotus Sutra and raising capital through stock listings of the Rissho-Katsue corporation. 


\section{Conclusion}

What was Kojima's faith based on? We think that Kojima kept acting based on a sense of mission. We can understand through his act of assisting his elder brother after the death of his parents. After discovering Tōitsu-Bushi, his performance of Nichiren's biography through Senō Hajime was also his mission, along with the establishment of Hokke-Clubinn and Rissho-Katsue corporation as ways of propagandizing Nichiren Buddhism. We can say that Nichiren's biography written by Senō Hajime was the origin of this sense of mission, leading him to the faith, and Nichiren's way of life moved him greatly.

\section{Notes}

1) We continue our studies about the faith of individuals and their change of a mind to profess Nichiren Buddhism, or 'Nichirenism' in modern Japan.

2) We were offered many documents by Naoto Kojima 小島直人, who is the grandchild of Ainosuke and Kojima's family head. Writing his name in collaboration, we will express our gratitude.

3) Syushiikkan, pp. 33-35.

4) This story was based on oral report from Kojima Naoto. There is a travel writing about the family temple of the Senō in Inori, vol. 389, March 1991, that Kojima Isondo wrote.

5) The handout of Kojima Isondo, 'Toitsu-Bushi, St. Nichiren's biography' In another handout, 'Kōsenrufu' 広宣流布, the object of Tōitsu-Bushi was written as follows: "basing on the ideal that it was important of reclaiming and advancing a corruption of minds of people, because Senō lamented over that appearance." However, he had not written the derivation of Tōitsu-Bushi.

6) St. Nichiren's biography, 'Table of Contents,' pp. 1-4.

7) We cannot discover texts of Nichiren's biography.

8) Showatēhon Nichiren shōnin ibun 昭和定本日蓮聖人遺文, p. 729: “We have to do two roads, learning and practicing. If we yield up to them, Buddhism will have to fall to the ground. Do it ourselves and enlighten everyone. Learning and a practicing come of faith."

9) The diary of 2nd January 1919.

10) The diary of 27th September 1919.

11) The diary of the same day: "We paid our respects at the hall putting in Nichiren's ash I remembered St. Nichiren who had come to suffer six times for our country, for the crown and for us. When I thought that there was the ash of St. Nichiren who had propagandized The Lotus Sutra in an attitude of oppressiveness 折伏弘通, it is hard to say, I was moved to tears and cried loudly self-unconsciously."

12) The diary of 1st January 1920: "I prayed please have the first child this year. Namu-Myō-Hō-RenGe-Kyō."

13) The diary of 27th August 1924.

14) Ibid.

Key words Kojima Ainosuke, Tōitsu-Bushi, Nichiren Buddhism

(Professor, Rissho University) 